\title{
PENGARUH BELANJA MODAL, BELANJA SOSIAL, DAN PERTUMBUHAN EKONOMI TERHADAP TINGKAT KEMISKINAN DI KOTA MANADO
}

\author{
Agustien Sendouw, Vekie A.Rumate, Debby Ch. Rotinsulu \\ Ekonomi Pembangunan - Fakultas Ekonomi dan Bisnis \\ Universitas Sam ratulangi
}

\begin{abstract}
ABSTRAK
Kemiskinan merupakan masalah klasik disetiap negara. Usaha pengentasan kemiskinan telah lama dilakukan oleh pemerintah. Variabel yang mempengaruhi tingkat kemiskinan antara lain adalah pengeluaran pemerintah dan pertumbuhan ekonomi. Pengeluaran pemerintah Kota Manado melalui pos belanja modal, belanja sosial, dan pertumbuhan ekonomi diharapkan juga memberi pengaruh terhadap tingkat kemiskinan. Penelitian ini bertujuan untuk mengetahui pengaruh belanja modal, belanjasosial, dan pertumbuhan ekonomi terhadap tingkat kemiskinan di Kota Manado secara parsial maupun secara bersama-sama. Metodeanalisis yang digunakan adalah analisis regresi berganda. Hasil penelitian menunjukan bahwa belanja modal memiliki pengaruh yang negative dan signifikan secara parsial terhadap tingkat kemiskinan sedangkan belanja social dan pertumbuhan ekonomi tidak memiliki pengaruh secara parsial terhadap tingkat kemiskinan di Kota Manado. Secara bersama-sama belanja modal, belanja sosial, dan pertumbuhan ekonomi tidak memiliki pengaruh terhadap tingkat kemiskinan di Kota Manado.
\end{abstract}

\section{Kata Kunci : Belanja Modal, Belanja Sosial, Pertumbuhan Ekonomi, Tingkat Kemiskinan.}

\begin{abstract}
Poverty is a classic problem in every country. Poverty eradication efforts have been carried out by the government. Variables that affect the level of poverty among other government are government expenditure and economic growth. Manado City Government expenditure through capital expenditure, social expenditure, and economic growth is expected to also make an impact on poverty levels. This research aimed to determine the effect of capital expenditure, social expenditure, and economic growth on poverty levels in Manado partially or jointly. The analytical method used is multiple regression analysis. The results showed that capital expenditure has a negative and significant effect partially to the poverty level while social spending and economic growth do not have a partial effect on poverty levels in the city of Manado. Taken all research variables found that capital expenditures, social expenditure, and economic growth have no effect on the level of poverty in the city of Manado.
\end{abstract}

Key Words : Regional Expenditure, Social Expenditure, Economic Growth, Poverty Level. 


\section{Latar Belakang Masalah}

\section{PENDAHULUAN}

Pembangunan ekonomi daerah pasca bergulirnya desentralisasi tahun 2001 yang diwujudkan dalam otonomi daerah hingga saat ini semakin berkembang setiap tahun. Transfer dana perimbangan yang diberikan pemerintah pusat ke daerah-daerah memacu semangat dan motivasi seluruh elemen daerah terutama pemerintah daerah sebagai pembuat kebijakan (decision makers) untuk melaksanakan pembangunan demi tercapainya kesejahteraan masyarakat di daerah. Syarat utama bagi pembangunan ekonomi ialah bahwa proses pertumbuhannya harus bertumpu pada kemampuan perekonomian didalam negeri. Hasrat untuk memperbaiki nasib dan prakarsa untuk menciptakan kemajuan material harus muncul dari warga negara itu sendiri. (Jhingan, $2007: 53$ ) Seiring dengan berlakunya otonomi daerah di Indonesia maka perencanaan pembangunan di daerah harus direncanakan dengan baik. Pembangunan akan berjalan baik apabila rencana penganggaran pembangunan dilakukan dengan cermat yang ditopang oleh sumber-sumber pendapatan daerah yang telah dikelola dengan baik. Salah satu tujuan perencanaan pembangunan yang baik adalah meningkatkan kesejahteran masyarakat atau dengan kata lain mengubah kondisi kehidupan masyarakat kearah yang lebih baik. Salah satu masalah dalam pembangunan adalah kemiskinan.Kemiskinan telah menjadi persoalan yang kompleks dalam suatu daerah arau negara, termasuk di Indonesia sebab kemiskinan merupakan masalah yang berifat multidimensional dan multisektor. Era otonomi daerah memberikan peluang yang besar bagi daerah untuk berkembang dan maju sesuai dengan kekayaan sumber daya yang terkandung di daerah masing-masing. Namun tak dipungkiri keberlangsungan otonomi daerah masih sangat bergantung dari dana pemerintah berupa dana perimbangan yang selalu di transfer oleh pemerintah daerah ke seluruh daerah di Indonesia pada setiap tahun anggaran. Anggaran yang ditransfer pemerintah pusat ke daerah akan menjadi sumber anggaran dan belanja yang paling besar dibanding pendapatan asli daerah. Oleh karena itu sudah seharusnya pengelolaan anggaran dan belanja yang disusun dalam berbagai perencanaan pembangunan di daerah pada akhirnya mampu meningkatkan kesejahteraan rakyat, antara lain mampu mengurangi tingkat kemiskinan di daerah.

Hal yang penting untuk dilihat adalah sejauh mana pembelanjaan yang dilakukan oleh pemerintah mampu memberikan pengaruh dan dampak pada peningkatan kesejahteraan rakyat yang signifikan dari tahun ke tahun.Semangat otonomi daerah harus mampu memberdayakan segenap potensi yang dimiliki daerah dan masyarakatnya untuk mewujudkan kesejahteraan dan kemajuan daerah. (Darise, 2006 : 14). Pembelanjaan yang dilakukan pemerintah daerah sudah seharusnya mampu mengurangi masalah kesejahteraan yang masih membelit sebagian masyarakat yakni kemiskinan.Pos-pos belanja yang langsung bersentuhan dengan kesejahteraan rakyat harus mendapat perhatian serius dari pemerintah daerah.Sesuai dengan aturan otonomi daerah dan pengelolaan keuangan daerah maka pos-pos yang paling vital menyentuh langsung kesejahteraan rakyat adalah Belanja Bantuan Sosial dan Belanja Modal.Belanja bantuan sosial memang dikhususkan untuk meningkatkan kesejahateraan masyarakat baik dalam bentukbarang maupun uang.Sedangkan Belanja modal merupakan pengeluaran pemerintah daerah untuk pembangunan seperti aset daerah, infrastruktur, sarana dan prasarana dasar di daerah. Oleh karena itu peran kedua jenis belanja ini sangat penting sebab jika belanja bantuan sosial dan belanja modal disalurkan tepat sasaran dan mengalami peningkatan setiap tahunnya maka diharapkan akan memberikan pengaruh terhadap kesejahteran masyarakat terutamamampu mengurangi tingkat kemiskinan. Pada sisi yang lain pengelolaan keuangan daerah yang baik 
dengan realisasi pembelanjaan tepat sasaran sesuai program kerja yang telah tersusun maka pengeluaran pemerintah akan berdampak positif terhadap perekonomian terutama pertumbuhan ekonomi. Peningkatan pertumbuhan ekonomi setiap periodenya akan berdampak pada peningkatan kesejahteraan masyarakat. Pertumbuhan ekonomi merupakan syarat keharusan (necessary condition) bagi pengurangan kemiskinan.Sedangkan syarat kecukupan (sufficient condition) ialah bahwa pertumbuhan ekonomi efektif dalam mengurangi kemiskinan.( Siregar : 2006). Realita yang terjadi di hampir seluruh daerah di Indonesia pasca otonomi daerah bergulir dalam hal pembelanjaan ialah bahwa share atau bagian belanja untuk pembangunan dan kehidupan sosial masih lebih rendah dibandingkan dengan belanja rutin dan operasional. Jika bagian belanja pembangunan atau belanja modal dan belanja sosial lebih rendah dari belanja rutin dan operasional maka akan berdampak pada tingkat kesejahteraan masyarakat terutama terhadap tingkat kemiskinan. Selain itu pengeluaran pemerintah juga memiliki hubungan erat dengan pertumbuhan ekonomi. Oleh karena itu jika pertumbuhan ekonomi rendah setiap periodenya pasti akan berdampak juga terhadap kesejahteraan masyarakat terutama terhadap tingkat kemiskinan. Anggaran pembangunan di Sulawesi Utara sampai saat ini masih mengandalkan dana transfer atau dana perimbangandari pemerintah pusat. Dana perimbnagan yang diterima pemerintah provinasi Sulawesi Utara terdiri atas bagi hasil pajak, bagihasil bukan pajak, Dana Alokasi Umum (DAU), dan Dana Alokasi Khusus (DAK),

Kota Manado sebagai ibukota Provinsi Sulawesi Utara sekaligus sebagai pusat perekonomian terbesar di jasirah utara pulau Sulawesi tidak akan pernah terlepas dari masalah kemiskinan. Peranan pemerintah Kota Manado dalam mengurangi tingkat kemiskinan tercermin dalam realisasi pembelanjaan dalam APBD setiap tahunnya terutama dalam realisasi pembelanjaan dalam pos belanja modal dan belanja sosial.Pada sisi yang lain, pertumbuhan ekonomi Kota Manado setiap tahunnya diharapkan dapat memberikan pengaruh terhadap penurunan tingkat kemiskinan. Usaha pemerintah Kota Mando dalam meningkatkan kesejahteraan dalam hal ini mengurangi tingkat kemiskinan juga dapat dilihat dari besaran dana atau belanja yang dikucurkan setiap tahunnya baik dalam sisi belanja tidak langsung maupun belanja tidak langsung. Namun realisasi belanja yang diharapkan dapat menyentuh langsung kesejahteraan masyarakat melalui pengurangan tingakt kemiskinan adalah melalui belanja modal dan belanja sosial serta besaran laju pertumbuhan ekonomi di Kota Manado.

Menurunnya realisasi belanja modal tahun 2010 serta belanja sosial tahun 2010 dan 2012 disebabkan oleh adanya pergeseran belanja dari pos belanja modal dan sosial dialihkan ke pos belanja rutin. Alokasi ini juga berkaitan dengan masalah keuangan daerah Kota Manado pada tahun-tahun sebelumnya.Hal yang lebih penting dari apa yang tercantum dalam tabel tersebut adalah bagaimana kaitan dan pengaruh antara varibael-variabel ekonomi yang adasebab data yang tercantum belum bisa menunjukkan adanya kaitan tersebut. Padahal dalam konsep keuangan daerah di era otonomi saat ini salah satu hal yang sangat penting adalah memahami dan mengetahui sejauh mana pengaruh dan dampak pengeluaran pemerintah dan perkembangan ekonomi terhadap indikator kesejahteraan masyarakat. Masalah yang sering terjadi pada perencanaan pembangunan dalam kaitannya dengan pengelolaan keuangan daerah ialah sejauh mana pengeluaran pemerintah dan pertumbuhan Ekonomi memberikan dampak terhadap kesejahteraan masyarakat. Berdasarkan hal inilah maka sangat penting untuk dilakukan kajian mengenai pengaruh belanja modal, belanja sosial dan pertumbuhan ekonomi terhadap tingkat kemiskinan di Kota Manado. 


\section{Perumusan Masalah}

Berdasarkan latar belakang permasalahan penelitian ini maka dapat dirumuskan masalah penelitian sebagai berikut :

1. Apakah belanja modal berpengaruh terhadap tingkat kemiskinan di Kota Manado ?

2. Apakah belanja sosial berpengaruh terhadap tingkat kemiskinan di Kota Manado ?

3. Apakah pertumbuhan ekonomi berpengaruh terhadap tingkat kemiskinan di Kota Manado ?

4. Apakah belanja modal, belanja sosial, dan pertumbuhan ekonomi secara bersama-sama berpengaruh terhadap tingkat kemiskinan di Kota Manado ?

\section{Tujuan Penelitian}

Adapun yang menjadi tujuan dari penelitian ini adalah :

1. Untuk mengetahui pengaruh belanja modal terhadap tingkat kemiskinan di Kota Manado.

2. Untuk mengetahui pengaruh belanja sosial terhadap tingkat kemiskinan di Kota Manado.

3. Untuk mengetahui pengaruh pertumbuhan ekonomi terhadap tingkat kemiskinan di Kota Manado.

4. Untuk mengetahui pengaruh belanja modal, belanja sosial, dan pertumbuhan ekonomi secara bersama-sama terhadap tingkat kemiskinan di Kota Manado.

\section{Manfaat Penelitian}

Manfaat penelitian ini adalah :

1. Menjadi masukan bagi pemerintah Kota Manado dalam membuat perencanaan dan kebijakan pembangunan terutama mengenai pembelanjaan dan pertumbuhan ekonomi terhadap tingkat kemiskinan.

2. Sebagai bahan referensi bagi penelitiian yang lain yang berkaitan dengan penelitian ini.

\section{Data dan Sumber Data}

\section{METODE PENELITIAN}

Data yang digunakan dalam penelitian ini adalah data sekunder time seriestahun 2006-2015 yang bersumber dari instansi yang memiliki kaitan dengan masalah dan variabel dalam penelitian ini antara lain dari Badan Pusat Statistik Kota Manadodan Propinsi Sulawesi Utara, Bagian Keuangan Sekeretariat Daerah Kota Manado.

\section{Metode Pengumpulan Data}

Metode pengumpulan data yang digunakan dalam penelitian ini adalah metode dokumentasi data dimana peneliti melakukan pengumpulan data dengan mendatangi langsung sumber data dan mengumpulkan data sekunder yang telah ada di instansi terkait.

\section{Definisi Operasional dan Pengukuran Variabel}

Variabel yang digunakan dalam penelitian ini adalah sebagai berikut :

1. Belanja Modal ialah bagian realisasi belanja APBD yang dikeluarkan oleh pemerintah Kota Manado yang dilakukan untuk pengadaaan aset tetap dan aset lainnya serta infrastruktur dan sarana-prasarana pembangunan dalam yang diukur dalam satuan Rp/tahun. 
2. Belanja Sosial ialah bagian realisasi belanja APBD yang dikeluarkan oleh pemerintah Kota Manado dalam bentuk uang maupun barang kepada masyarakat yang benar-benar membutuhkannya di Kota Manado dan diukur dalam satuan Rp/tahun.

3. Pertumbuhan Ekonomi ialah pertumbuhan dari nilai riil perekonomian Kota Manado yakni pertumbuhan PDRB Riil (ADHK) setiap tahunnya yang diukur dalam satuan Rp/tahun.

4. Tingkat Kemiskinan ialah persentase jumlah masyarakat miskin yang ada diKota Manado terhadap total jumlah penduduk Kota Manado yang diukur dalam satuan persen per tahun.

\section{Metode Analisis Data}

Metode analisis yang digunakan dalam penelitian ini adalah :

1. Analisis Deskriptif ; metode ini berupa metode analisa tabel yang bertujuan untuk mengkaji dan menganalisa perkembangan yang terjadi dalam perekonomian di Kota Manado secara umum dan lebih khusus lagi mengenai perkembangan belanja sosial,belanja modal,pertumbuhan ekonomi dan kemiskinan.

2. Analisis Statistik Inferensia; Analisis statistik yang digunakan adalah analisis regresi berganda dengan rumus sebagai berikut :

a. $\quad \mathbf{Y}=\boldsymbol{\beta} \mathbf{0}+\boldsymbol{\beta} \mathbf{1 X 1}+\boldsymbol{\beta} 2 \times \mathbf{2}+\boldsymbol{\beta} 3 \mathbf{X} \mathbf{3}+\mathbf{e}$; dimana :

$\mathrm{Y}=$ Tingkat Kemiskinan(Variabel Terikat)

$\beta \mathrm{o}=$ Konstanta

$\beta 1, \beta 2, \operatorname{dan} \beta 3=$ Koefisien Regresi

$\mathrm{X} 1=$ Belanja Modal (Variabel Bebas 1)

$\mathrm{X} 2$ = Belanja Sosial (Variabel Bebas 2)

$\mathrm{X} 3$ = Pertumbuhan Ekonomi (Variabel Bebas 3)

$\mathrm{e}=$ Parameter Pengganggu

b. Koefiesien Determinasi Berganda $\left(\mathrm{R}^{2}\right)$ yakni besarnya proporsi atau sumbangan ketiga variabel bebas terhadap perubahanvariabel terikat dengan menggunakan rumus koefisien determinasi berganda yakni :

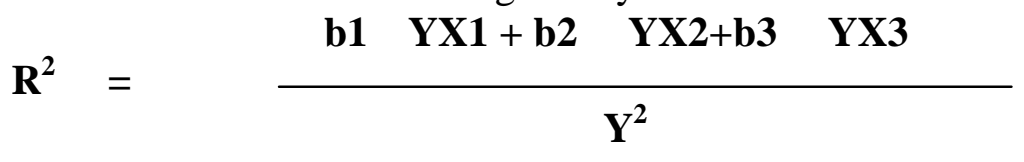

Nilai $\mathrm{R}^{2}$ terletak antara 0 dan 1 . Jika $\mathrm{R}^{2}=1$ berarti 100 persen total variasi veriabel terikat dijelaskan oleh variabel-variabel bebasnya dan menunjukkan ketepatan terbaik.Bila $\mathrm{R}^{2}=0$ berarti tak ada total variasi variabel terikat yang dijelaskan oleh variabel bebasnya (Wirawan, $2002:$ 299-300).

c. Koefisien korelasi berganda $(\mathrm{R})$; dalam regresi berganda nilai korelasi berganda selalu bernilai positif. Koefisien korelasi berganda digunakan untuk melihat keeratan hubungan antara variabel bebas secara bersama-sama terhadap variabel terikat.

Rumus yang digunakan adalah $: \mathbf{R}=\sqrt{ } \mathbf{R}^{2}$. Jika $R=1$ berarti terdapat korelasi linier sempurna dan positif antara variabel bebas dengan variabel terikat . Jika $R=-1$ maka terdapat korelasi linier sempurna dan negatif sedangkan jika $\mathrm{R}=0$ tidak ada korelasi antara variabel bebas dengan variabel terikat. 
d. Uji signifiknasi secara individual (uji t) bertujuan untuk menguji apakah koefisien regresi parsial berbeda secara signifikan (nyata) dari 0 atau apakah suatu variabel bebas secara individu berpengaruh terhadap variabel terikatnya.

$$
\text { Rumusnya adalah : } \mathrm{t}=\mathrm{bi}-\beta \mathrm{i} / \mathrm{Sbi}
$$

Hipotesis yang digunakan adalah:

$$
\begin{array}{ll}
\text { Ho }: & \beta_{\mathrm{i}}=0 \\
\text { Ha }: & \beta_{\mathrm{i}} \nRightarrow
\end{array}
$$

dengan menentukan derajat keyakinan $95 \%(\alpha=0,05)$ dimana :

Jika t-hitung $\leq$ t-tabel $\alpha / 2(n-k)$ maka Ho di terima

Jika t-hitung $\geq$ t-tabel $\alpha / 2(n-k)$ maka Ho di tolak

e. Uji signifikansi serempak (uji F)bertujuan untuk menguji apakah koefisien regresi parsial secara serempak atau bersama-sama berbeda secara signifikan dari 0 atau apakah ada pengaruh yang signifikan variabel bebas X1 dan X2 secara serempak terhadap variabel terikat $\mathrm{Y}$.

$$
\text { Rumusnya adalah : } \mathrm{F}=\mathrm{R}^{2} /(\mathrm{k}-1) /\left(1-\mathrm{R}^{2}\right) /(\mathrm{n}-\mathrm{k}) \text {. }
$$

Hipotesis yang digunakan adalah : $\mathrm{H} 0: \beta 1=\beta 2=0$

$$
\mathrm{H} 1: \beta 1 \neq \beta 2 \neq 0
$$

\section{Uji Asumsi Klasik}

Untuk meyakinkan bahwa model regresi yang telah diolah dengan program SPSS for Windows dapat mengukur kekuatan relasi atau hubungan yang saling ketergantungan antara variabel terikat (dependen) dengan satu atau lebih variabel bebas (independen) melalui suatu persamaan, serta sah atau validnya digunakan sebagai peramalan nilai variabel independen, maka model regresi yang dipakai dalam penelitian harus bebas dari uji asumsi klasik. Uji asumsi klasik ini meliputi :

A. Uji Autokorelasi ;Uji ini merupakan pengujian asumsi dalam regresi di mana variabel dependen tidak berkorelasi dengan dirinya sendiri. Maksud berkorelasi dengan dirinya sendiri adalah bahwa nilai dari variabel dependen atau variabel terikat tidak berhubungan dengan nilai variabel itu sendiri, baik nilai periode sebelumnya atau nilai periode sesudahnya. Untuk mendeteksi gejala autokorelasi maka menggunakan uji Durbin- Watson (DW). Uji ini menghasilkan nilai DW hitung (d) dan nilai DW tabel ( $\mathrm{dl} \& \mathrm{du}$ ). Aturan pengujiannya adalah $: \mathrm{d}<\mathrm{dl}$ berarti terjadi masalah autokorelasi yang positif yang perlu perbaikan.

$\mathrm{dl}<\mathrm{d}<\mathrm{du}$ berarti ada masalah autokorelasi positif tetapi lemah, dimana perbaikan akan lebih baik dilakukan.

$\mathrm{dl}<\mathrm{d}<4$-du berarti tidak ada masalah autokorelasi.

4-du<d<4-dl berarti masalah autokorelasi lemah, dimana dengan perbaikan akan lebih baik.

4-dl < d berarti masalah autokorelasi serius(Santosa dan Ashari, 2005 :240-241).

B. Uji Multikolinearitas ; Asumsi multikolinieritas menyatakan bahwa variabel independen harus terbebas dari gejala multikolinieritas. Gejala multikolinearitas adalah gejala korelasi antar variabel independen. Gejala ini ditunjukkan dengan korelasi yang signifikan antar variabel independen. Dengan kata lain multikolinieritas berarti adanya hubungan linear yang sempurna atau pasti diantara beberapa atau semua variabel yang menjelaskan dari model regresi.

(Gujarati, 2005 : 157). Melalui pendekatan 
olahan data dengan SPSS maka gejala multikolinieritas dapat dilihat melalui nilai VIFpada tabel Coefficients dimana jika nilai VIF lebih rendah dari 10 maka tidak terjadi gejala multikolinearitas atara variabel bebas. Selain itu gejala multikolonearitas dapat dilihat melalui Coefficient Correlations Matrix. Jika korelasi antara sesamavariabel bebas lebih rendah dari 0,5 maka tidak terjad gejala multikolinearitas antar variable bebas.( Santosa\& Ashari, 2005 : 238 -240).

C. Uji Heteroskedastisitas ; salah satu asumsi dalam regresi linear klasik adalah bahwa gangguan (disturbance) uji yang muncul dalam fungsi regresi populasi adalah homoskedastik yaitu semua gangguan tadi mempunyai varians yang sama. (Gujarati 2005, : 177). Dalam regresi varians dari residual dari satu pengamatan ke pengamatan yang lain idak memiliki pola tertentu. Pola yang tidak sama ini ditunjukkan dengan nilai yang tidak sama antar satu varians dari residual. Gejala varians yang tidak sama in disebut dengan gejala heteroskedastisitas, sedangkan adanya gejala varians residual yang sama dari satu pengamatan ke pengamatan yang lain disebut dengan homokedastisitas. Salah satu uji untuk menguji heteroskedastisitas dalam program SPSS adalah dengan melihat penyebaran dari varians residual ( Santosa\& Ashari, 2005 : 242).

\section{Uji Normalitas Data}

Uji normalitas dilakukan untuk menguji apakah dalam model regresi, variabel penggangu atau residual memiliki distribusi normal.Model regresi yang baik adalah berdistribusi normal atau mendekati normal. Untuk mengetahui ada tidaknya normalitas dalam model regresi, yaitu dengan melihat normal probability plot yang membandingkan distribusi komulatif dari distribusi normal. Distribusi normal akan membentuk satu garis lurus diagonal dan ploting data residual akan dibandingkan dengan garis diagonal. Jika distribusi data residual normal, maka garis yang menggambarkan data sesungguhnya akan mengikuti garis diagonalnya (Ghozali, 2009). Pada prinsipnya normalitas dapat dideteksi dengan melihat penyebaran data (titik) pada sumbu diagonal dari grafik atau dengan melihat histogram dari residualnya.

Adapun dasar pengambilan keputusan sebagai berikut (Ghozali, 2009):

- Jika data menyebar di sekitar garis diagonal dan mengikuti arah garis diagonal, maka model regresi memenuhi normalitas.

- Jika data menyebar jauh dari garis diagonal dan tidak mengikuti arah garis diagonal, maka model regresi tidak memenuhi normalitas.

Uji normalitas dengan grafik dapat menyesatkan karena secara visual dapat kelihatan tidak normal padahal secara statistik atau sebaliknya. Adapun uji normalitas dengan statistik yang digunakan dalam penelitian ini adalah uji Kolmogorov-Smirnov (KS test), yaitu dengan melihat angka profitabilitas signifikan dimana data dapat disimpulkan berdistribusi normal jika angka signifikannya lebih besar dari 0,05 .

\section{Uji Asumsi Klasik}

\section{HASIL DAN PEMBAHASAN}

Uji asumsi klasik dalam penelitian ini menggunakan bantuan Software SPSS 17hasilnya adalah sebagai berikut :

a. Uji Auto Korelasi

\begin{tabular}{|c|}
\hline Durbin-Watson \\
\hline 2,488 \\
\hline
\end{tabular}


$\mathrm{H} 0=$ tidak ada serial autokorelasi baik positif atau negatif,maka jika du $<\mathrm{d}<4$-du tidak menolak H0 atau tidak ada masalah autokorelasi. (Gujarati 2005 :218). du =0,82 maka 0,82 < $2,488<4-0,82$ sehingga $0,82<2,488<3,18$. Berdasarkan hasil ini maka tidak ada masalah autokorelasi.

b. Uji Multikolinieritas

\begin{tabular}{|l|c|c|}
\hline \multirow{2}{*}{ Model } & \multicolumn{2}{|c|}{ Collinearity Statistics } \\
\cline { 2 - 3 } & Tolerance & VIF \\
\hline (Constant) & & \\
Belanja Modal & 0,959 & 1,043 \\
Belanja Sosial & 0,966 & 1,035 \\
Pertumbuhan Ekonomi & 0,991 & 1,009 \\
\hline
\end{tabular}

Hasil uji multikolinieritas menunjukkan bahwa nilai VIF dari variabel belanja modal, belanja sosial dan pertumbuhan ekonomi adalah lebih kecil dari 10.Hal ini menunjukkan bahwa tidak terjadi gejala multikolineritas didalam variabel penelitian ini. Selain dengan melihat nilai VIF maka untuk mendektesi gejala multikolinearitas maka dqpat dilihat pada nilai koefisien korelasi antar variabel bebas. Hasil adalah sebagai berikut :

\section{Coefficient Correlations ${ }^{\mathrm{a}}$}

\begin{tabular}{|cll|l|l|l|}
\hline \multicolumn{2}{|c|}{ Model } & & $\begin{array}{c}\text { Pertumbuhan } \\
\text { Ekonomi }\end{array}$ & $\begin{array}{c}\text { Belanja } \\
\text { Sosial }\end{array}$ & $\begin{array}{c}\text { Belanja } \\
\text { Modal }\end{array}$ \\
\hline 1 & Correlations & Pertumbuhan & 1.000 & -.021 & -.089 \\
& & Ekonomi & & \\
& & Belanja Sosial & $\mathbf{- . 0 2 1}$ & 1.000 &.$- \mathbf{1 8 1}$ \\
& Belanja Modal & $\mathbf{- . 0 8 9}$ &.- .181 & 1.000 \\
\hline \multirow{6}{*}{ Covariances } & Pertumbuhan & .047 & -.001 & -.020 \\
& Ekonomi & & & \\
& & Belanja Sosial & -.001 & .056 & -.045 \\
& Belanja Modal & -.020 & -.045 & 1.119 \\
\hline
\end{tabular}

a. Dependent Variable: Tingkat Kemiskinan

Nilai koefisien korelasi antara ketiga variabel lebih rendah dari 0,5. pertumbuhan sehingga dengan demikian tidak terdapat multikolinearitas (Santosa dan Ashari, 2005 : 240).

c. Uji Heteroskedastisitas 


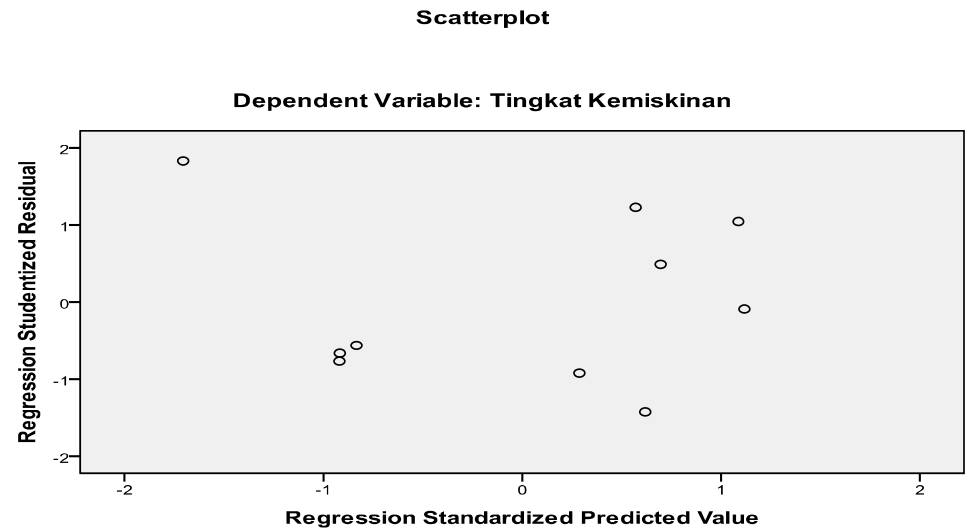

Hasil uji heteroskedastisias memperlihatkan sebaran residual dalam scatterplot terpencar tidak beraturan atau tidak membentuk suatu pola tertentu yang rapi dan teratur.Oleh karena itu berdasarkan hal ini maka di dalam penelitian ini tidak terjadi gejala homokedastisitas atau persamaan memenuhi asumsi heterokedastisitas.

\section{Uji Normalitas Data}

Uji normalitas data bertujuan untuk menguji data-data tentang variabel yang digunakan dalam penelitian ini apakah sudah tersebar secara normal atau tidak.Sebelum digunakan dalam model regresi berganda maka variabel-varibel penelitian perlu di uji kenormalan datanya.Asumsi yang digunakan adalah bahwa data peneltian adalah data yang tersebar secara normal atau tersebar mendekati sumbu regresi.Uji normalitas data dalam penelitian ini menggunakan Test Kolmogorov-Smirnov dengan Software Program SPSS 17.

Hasil uji normalitas data adalah sebagai berikut :

One-Sample Kolmogorov-Smirnov Test

\begin{tabular}{|ll|r|r|r|r|}
\hline \multicolumn{2}{|c|}{ Indikator } & $\begin{array}{c}\text { Belanja } \\
\text { Modal }\end{array}$ & Belanja Sosial & $\begin{array}{c}\text { Pertumbuh } \\
\text { an } \\
\text { Ekonomi }\end{array}$ & $\begin{array}{c}\text { Tingkat } \\
\text { Kemiskinan }\end{array}$ \\
\hline \multirow{2}{*}{ Normal } & & \multicolumn{1}{c|}{10} & 10 & 10 & 10 \\
Parameters & Mean & $1,116.60$ & $1,011.90$ & 718.20 & 565.90 \\
& Std. & 17.283 & 76.866 & 83.035 & 75.851 \\
Most Extreme & Deviation & & & & \\
Differences & Absolute & .209 & .198 & .211 & .209 \\
& Positive & .132 & .191 & .211 & .209 \\
Kolmogorov-Smirnov Z & -.209 & -.198 & -.161 & -.208 \\
Asymp. Sig. (2-tailed) & .662 & .627 & .666 & .659 \\
\hline
\end{tabular}

Hasil uj normalitas data menunjukkan bahwa nilai Asymp. Sig. (2-tailed) untuk variabel Belanja Modal adalah 0,774 variabel Belanja Sosial sebesar 0,827 variabel Pertumbuhan Ekonomisebesar 0,767 dan variabel terikat Tingkat Kemiskinan sebesar 0,777. Oleh karena 
keempat variabel memiliki nilai Asymp.Sig. (2-tailed) lebih besar dari 0,05 maka dapat disimpulkan bahwa data yang digunakan dalam penelitian ini tersebar secara normal

\section{Hasil Uji Regresi Berganda dan Pengaruh Secara Parsial}

Hasil uji regresi berganda dan uji parsial adalah sebagai berikut :

\begin{tabular}{|l|c|c|c|c|}
\hline \multirow{2}{*}{ Model } & \multicolumn{2}{|c|}{$\begin{array}{c}\text { Unstandardized } \\
\text { Coefficients }\end{array}$} & $\begin{array}{c}\text { Standardize } \\
\text { d } \\
\text { Coefficients }\end{array}$ & \multirow{2}{*}{$\mathbf{t}$} \\
\cline { 2 - 4 } & B & Std. Error & Beta & \\
\hline (Constant) & 37.560 & 11.576 & - & 3.245 \\
Belanja Modal & -3.297 & 1.058 & -.751 & -3.117 \\
Belanja Sosial & .224 & .237 & .227 & .946 \\
Pertumbuhan Ekonomi & .369 & .217 & .403 & 1.702 \\
\hline
\end{tabular}

Persamaan Regresi $\quad \hat{\mathbf{Y}}=\mathbf{3 7 , 5 6 0}-\mathbf{3 , 2 9 7 B M}+\mathbf{0 , 2 2 4 B S}+\mathbf{0 , 3 6 9 P E}$ Interpretasi dari persamaan regresi ini adalah sebagai berikut :

A. Nilai konstanta 37,560 mengandung arti belanja modal,belanja sosial dan pertumbuhan ekonomi belum memiliki nilai atau nol maka tingkat kemiskinan adalah sebesar 37,560 $\%$.

B. Jika belanja modalmeningkat sebesar $1 \%$ maka tingkat kemiskinan akan mengalami penurunan sebesar 3,297\%.

C. Jika belanja sosial bertambah sebesar $1 \%$ maka tingkat kemiskinan akan meningkat sebesar $0,224 \%$.

D. Jika pertumbuhan ekonomi bertambah sebesar $1 \%$ maka tingkat kemiskinan akan meninngkat sebesar $0,369 \%$

Pengaruh variabel bebas terhadap variabel terikat secara parsial atau sendiri-sendiri dapat dilihat

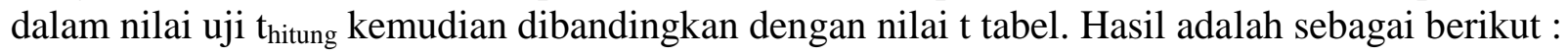

A. $t_{\text {hitung }}$ untuk variabel belanja modal $=-3,117$ sedangkan $t$ tabel $\left(\alpha_{0,05 / 2} ; 10-3\right.$ menjadi $\alpha$ 0,$025 ; 7$ ) memiliki nilai $t$ tabel sebesar : 2,365 . Hasil ini menunjukkanbahwa $t_{\text {hitung }}(-$ 3,117)jatuh di daerah sebelah kiri kurva normal (jatuh di daerah penolakan Ho) sebab nilai t tabel sebelah kiri kurva normal adalah -2,365.dengan demikian maka variabel belanja modal memiliki pengaruh secara parsial terhadap terhadap tingkat kemiskinan. Pengaruh belanja modal terhadap tingkat kemiskinan di Kota Manado adalah negatif artinya jika belanja modal meningkat maka tingkat kemiskinan akan mengalami penurunan.

B. $t_{\text {hitung }}$ untuk variabel belanja sosial $=0,946$ sedangkan $t$ tabel $\left(\boldsymbol{\alpha}_{0,05 / 2} ; 10-3\right.$ menjadi $\alpha_{0,025 ; 7)}$ memiliki nilai t tabel sebesar : 2,365 . Hasil ini menunjukkan bahwanilai $t_{\text {hitung }}(0,946)<$ t tabel $(2,365)$ dengan demikian maka variabel belanja sosial tidak memiliki pengaruh secara parsial terhadap tingkat kemiskinan.

C. $t_{\text {hitung }}$ untuk variabel pertumbuhan ekonomi $=1,702$ sedangkan $t$ tabel $\left(\alpha_{0,05 / 2 ; 10-3}\right.$ menjadi $\alpha_{0,025 ; 7}$ ) memiliki nilai t tabel sebesar : 2,365. Hasil ini menunjukkan bahwa nilai $t_{\text {hitung }}(1,702)<t$ tabel $(2,365)$, dengan demikian maka variabel pertumbuhan ekonomi tidak memiliki pengaruh secara parsial terhadap tingkat kemiskinan. 


\section{Pengaruh Variabel Bebas terhadap Variabel Terikat secara Bersama-sama atau Simultan}

Pengaruh variabel belanja modal, belanja sosial, dan pertumbuhan ekonomi terhadap tingkat

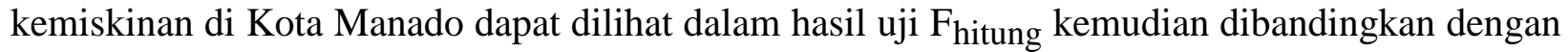
nilai $\mathrm{F}$ tabel. Hasilnya adalah sebagai berikut :

\begin{tabular}{|c|c|c|c|c|c|c|}
\hline \multicolumn{7}{|c|}{ ANOVA $^{\text {b }}$} \\
\hline \multicolumn{2}{|c|}{ Model } & $\begin{array}{l}\text { Sum of } \\
\text { Squares }\end{array}$ & $\mathrm{df}$ & $\begin{array}{c}\text { Mean } \\
\text { Square }\end{array}$ & $\mathrm{F}$ & Sig. \\
\hline 1 & Regression & 3.448 & 3 & 1.149 & 3.987 & $.071^{\mathrm{a}}$ \\
\hline & Residual & 1.730 & 6 & .288 & & \\
\hline & Total & 5.178 & 9 & & & \\
\hline
\end{tabular}

a. Predictors: (Constant), Pertumbuhan Ekonomi, Belanja Sosial, Belanja Modal

b. Dependent Variable: Tingkat Kemiskinan

A. Nilai $F_{\text {hitung }}$ adalah sebesar 3,987

B. Nilai Ftabel untuk 3 variabel bebas $(k=3)$ dengan $n-k(10-3)$ atau 3 variabel bebas dan $n$ $=7$ adalah 4,35

C. Nilai $F_{\text {hitung }}(6,705)<$ Nilai $F$ tabel $(4,35)$, dengan demikian maka secara bersama-sama atau simultan maka variabel belanja modal,belanja sosial, dan pertumbuhan ekonomitidak memiliki pengaruh secara bersama-sama (simultan) terhadap tingkat kemiskinan.

\section{Korelasi antara Variabel Bebas Dengan Variabel Terikat}

Korelasi atau keeratan hubungan antara variabel bebas dengan variabel terikat dapat dilihat dalam besarnya hasil uji korelasi yakni uji R :

\begin{tabular}{|c|c|c|c|c|}
\hline Model & $\mathbf{R}$ & $\begin{array}{c}\mathbf{R} \\
\text { Square }\end{array}$ & $\begin{array}{c}\text { Adjusted R } \\
\text { Square }\end{array}$ & $\begin{array}{c}\text { Std. Error } \\
\text { of the } \\
\text { Estimate }\end{array}$ \\
\hline $\mathbf{1}$ & $.816^{\mathrm{a}}$ & .666 & .499 & .53695 \\
\hline
\end{tabular}

Hasil uji R menunjukkan bahwa keeratan hubungan antara belanja modal,belanja sosial, dan pertumbuhan ekonomi sebagai variabel bebas dalam penelitian ini dengan tingkat kemiskinan sebagai variabel terikat adalah sebesar $81,6 \%$. Hal ini berarti bahwa antara variabel bebas dengan variabel terikat terdapat hubungan yang erat dan kuat yang bersifat positif

\section{Kontribusi Variabel bebas terhadap Variabel Terikat}

Kontribusi atau determinasi variabel bebas terhadap variabel terikat dalam penelitian ini dpat diliaht dalam uji determinan ( $R$ Square atau $\mathrm{R}^{2}$ ). Hasil yang tercantum dalam tabel diatas menunjukkan bahwa nilai $\mathrm{R}$ Square adalah sebesar 0,666 atau 66,6 \%. Hal ini berarti bahwa kontribusi belanja modal, belanja sosial dan pertumbuhan ekonomi terhadap tingkat kemiskinan di Kota Manado adalah sebesar 66,6 \% sedangkan sisanya sebesar 33,4 \% disumbangkan oleh variabel lain yang tidak di kaji dalam penelitian ini. 


\section{Pembahasan}

Berdasarkan hasil penelitian maka dapat dibahas beberapa hal penting sebagai berikut :

1. Hasil penelitian menunjukkan bahwa nilai koefisien regresi untuk variabel belanja sosial dan pertumbuhan ekonomi adalah positif. Hal ini agak bertentangan dengan teori tentang kemiskinan dalam kaitannya dengan kebijakan pengelolaan keuangan daerah.

2. Hasil penelitian mengenai uji t (parsial) untuk variabel belanja sosial dan pertumbuhan ekonomi secara parsial tidak berpengaruh terhadap tingkat kemiskinan di Kota Manado. Uji F (Simultaan) juga menunjukkan secara bersama-sama ketigavariabel bebas tidak berpengaruh terhadap tingkat kemskinan di Kota Manado. Hal ini juga bertentangan dengan teori keuangan daerah dan semangat Undang-Undang Otonomi Daerah.

Apabila didasarkan pada teori pengeluran pemerintah dan pengaruhnya terhadap kemiskinan (Jhingan, M.L, 1996) serta teori mengenai pertumbuhan ekonomi dan pengaruhnya terhadap kemiskinan (Murni,2006) maka hasil penelitian ini sebagian besar memiliki hasil yang agak bertolak belakang dengan teori-teori tersebut. Namun secara parsial pengeluaran pemerintah Kota Manado melalui belanja modal,masih memiliki pengaruh yang signifikan dan bersifat negatif terhadap tingkat kemiskinan di Kota Manado. Pada posisi hasil ini, hasil pnenlitian masih sesuai dengan teori mengenai pengeluaran dan pengaruhnya terhadap kemiskinan. Apabila dibandingkan dengan hasil penelitian terdahulu yang digunakan dalam penelitian ini seperti hasil penelitian oleh Daniel J.Sumbayak,dkk, Universitas Indonesia, 2015, yang berjudul "Pengaruh pertumbuhan ekonomi terhadap tingkat kemiskinan di Provinsi Sumatera Selatan" dengan metode ekonometrika linier berganda (multipleregression) yang menunjukkan hasil bahwa pertumbuhan ekonomi memiliki pengaruh yang signifikan terhadap tingkat kemiskinan dimana variabel pertumbuhan mampu menurunkan tingkat kemiskinan di Provinsi Sumatera Selatan, maka hasil penelitian ini berbeda dengan hasil penelitian tersebut diatas, sebab hasil penelitian ini menunjukkan bahwa pertumbuhan ekonomi tidak berpengaruh signifikan terhadap tingkat kemiskinan di Kota Manado.

Kurang sesuainya hasil penelitian ini dengan landasan teori dan penelitian terdahulu bukan berarti bahwa penelitian ini tidak mengikuti kaidah metodologi penelitian dan statistika ekonometrika yang benar.Pemilihan variabel penelitian sudah sesuai dengan dasar teori keuangan daerah. Semangat otonomi daerah memberikan kebebasan sebesarnya kepada seluruh stakeholder di daerah terutama pemerintah daerah (kabupaten/kota) untuk menggali semua potensi dan sumber daya yang ada di daerah untuk dijadikan sebagai sumber pendapatan asli. Namun ketergantungan terhadap dana perimbangan terutama untuk belanja modal dan belanja sosial sangatlah tinggi. Hasil penelitian menunjukkan bahwa realisasi anggaran pada pos belanja bantuan sosial tidak memiliki pengaruh terhadap tingkat kemiskinan di Kota Manado.Hal ini mengandung arti bahwa bantuan sosial yang diberikan selama ini oleh pemerintah Kota Manado terhadap masyarakat kecil yang cenderung kurang mampu belum bisa meningkatkan taraf hidup masyarakat miskin yang ada di Kota Manado. Hasil kajian juga menunjukkan bahwa pertumbuhan ekonomi tidak berpengaruh terhadap tingkat kemiskinan di Kota Manado. Hal ini dapat dikatakan bahwa pertumbuhan ekonomi yang terjadi di Kota Manado selama sepuluh tahun terakhir kurang berpihak pada golongan masyarakat yang kurang mampu di Kota Manado. Berdasarkan hasil penelitian maka jika dikaitkan dengan kebijakan pemerintah Kota Manado dalam kaitannya dengan program-program pengentasan kemiskinan, belanja sosial diharapkan seharusnya diberikan kepada kelompok masyrakat yang seharusnya yang pantas menerima. Program pemberian bantuan juga dapat diperbesar anggarannya dan diberikan melalui bantuan yang memangdibutuhkan masyrakat dan mampu meningkatkan kehidupan mereka misalnya 
dengan pemberian modal usaha dan bantuan alat untuk berusaha sesuai kemampuan mereka masing-masing. Pertumbuhan ekonomi Kota Manado memang lebih banyak disumbangkan oleh sektor tersier dimana kelompok masyarakat miskin justru kurang terserap dan terlibat dalam sektor-sektor utama yang banyak memberi kontribusi terhadap perekonomian Kota Manado. Oleh karena itu seberapa pun pertumbuhan ekonomi meningkat maka kemampuan masyarakat miskin untuk terlibat dalam perputaran kegiatan ekonomi Kota Manado akan kurang sehingga dengan sendirinya pengaruh pertumbuhan ekonomi kurang berpengaruh terhadap peningkatan kesejahteraan kelompok masyarakat kurang mampu di Kota Manado.

\section{DAFTAR PUSTAKA}

Aiyedogbon,J.O, Ohfowasa, B.O, Anyanwu, S, 2015, Government Expenditure and Economic Growth in Nigeria, 1981-2013: A Bound Testing Approach, International Journal of Economics and Financial Research ISSN: 2411-9407 Vol. 1, No. 4, pp: 50-56, 2015, URL: http://arpgweb.com/?ic=journal\&journal=5\&info=aims

Amalia,Rahmah., Madris, Abd. Rahman Razak, 2015, Pengaruh Pengeluaran Pemerintah Terhadap Kemiskinan di Provinsi Sulawesi Barat, Jurnal Analisis, Jurusan Ekonomi Pembangunan dan Perencanaan Fakultas Ekonomi, Pascasarjana Universitas Hasanuddin Makasar, Desember 2015 Vol.4,No.2 : 183-189, ISSN 2303-100X.

Boediono, 2001, Teori Pertumbuhan Ekonomi, BPFE UGM, Yogyakarta

Darise,Nurlan, 2006, Pengelolaan Keuangan Daerah, Penerbit PT.Indeks, Jakarta

Dalimunthe, Masniari. 2008. Analisis Pengaruh Pengeluaran Pemerintah Pada Sektor Pendidikan dan Kesehatan Terhadap Penduduk Miskin di Sumatera Utara. Fakultas Ekonomi, Universitas Sumatera Utara

Daryanto Arief \& Hafizrianda Yundy, 2010, Model-Model Kuantitatif Untuk Perencanaan Pembangunan Ekonomi Daerah Konsep dan Aplikasi, Penerbit IPB Press Bandung.

Dahmardeh Nazar, Dr.,\& Mahmoud Hashemi Tabar,2013, Government Expenditures and its Impact on Poverty Reduction (Empirical From Sistan and Baluchestan Province of Iran), International Journal of Academic Research in Economics and Management Sciences January 2013, Vol. 2, No. 1 ISSN: 2226-3624 .

Gujarati, Damodar, 2005, Ekonometrika Dasar, Alih Bahasa Sumarno Zain, Penerbit

Erlangga ,Jakarta.

Ghozali,.Imam 2009. Ekonometrika: Teori, Konsep dan Aplikasi dengan SPSS 17. Badan PenerbitUniversitas Diponegoro, Semarang

Halim, Abdul, 2002. Akuntansi Keuangan Daerah, Edisi 3 Akuntansi Sektor Publik, Penerbit Salemba Empat, Jakarta.

Haryani. 2009. Pengaruh Pertumbuhan Ekonomi, Belanja Daerah dan Jumlah Penduduk Terhadap Kemiskinan (Studi Kasus Kab/Kota di Provinsi Jawa Tengah Tahun 2007). Fakultas Ekonomi, Universitas Negeri Semarang

Irawan-Suparmoko, 1992, Ekonomika Pembangunan, Edisi 5, Penerbit Badan Penerbit Universitas Gadjah Mada Yogyakarta

Ijaiya,Gafar.T., Mukaila A.Ijaiya, Raji A.Bello, Michael A.Ajayi, 2011, Economic Growth and Poverty Reduction in Nigeria, International Journal of Business and Social Science Vol. 2 No. 15; August 2011.

Jhingan, M.L, 1996, Ekonomi Pembangunan dan Perencanaan, Penerbit PT.RajaGrafindo, Jakarta. 
Kuncoro,.Mudrajad,2004,Otonomi dan Pembangunan Daerah, Reformasi, $\quad$ Perencanaan, Strategi dan Peluang, Penerbit UPP STIM YKPN Yogyakarta.

Murni, Asfiah (2006), Ekonomika Makro, Penerbit PT.Rafika Aditama, Bandung.

Mankiw, N.Gregory, 2007, Teori Ekonomi Makro, Edisi4, Penerbit Erlangga Jakarta

Mustika,Candra, (2011) Pengaruh PDB dan Jumlah Penduduk Terhadap Kemiskinan di Indonesia (1990-2008)-Jurnal Paradigma Ekonomika Vol.1 No.1 4 Oktober 2011.

Nindi Angelique G. and Nicholas M. Odhiambo,2012, Poverty and Economic Growth in Swaziland:An Empirical Investigation,Managing Global Transitions 13 (1): 59-74

Nurmainah, Siti (2013), Analisis Pengaruh Belanja Modal Pemerintah Daerah ,Tenaga Kerja Terserap dan Indeks Pembangunan Manusia Terhadap Pertumbuhan Ekonomi dan Kemiskinan (Studi kasus 35 kabupaten/kota di Provinsi Jawa Tengah)- Jurnal Bisnis dan Ekonomika (IBE) September 2013 Vol.3 No.2 Undip Semarang.

Rustam, 1997, Perencanaan Pembangunan Wilayah, Penerbit Institut Teknologi Bandung

Rahardja,Pratama \& Mandala Manurung., 2004, Pengantar Ilmu Ekonomi, (Mikroekonomi dan Makroekonomi), Edisi Revisi, Penerbit Fakultas Ekonomi UI, Jakarata

Republik Indonesia,Undang-Undang No. 32 tahun 2004 tentang Pemerintah Daerah

Republik Indonesia, Peraturan Pemerintah Republik Indonesia Nomor 58 Tahun 2005 tentang Pengelolaan Keuangan Daerah.

Suroto, 1992, Strategi Pembagunan dan Perencanaan Kesempatan Kerja, Penerbit Universitas Gajah Mada, Yogyakarta

Samuelson, Paul A \& Nordhaus, William D, Nordhaus, 1996 Makro Ekonomi (terjemahan), Edisi Keempatbelas, Penerbit Erlangga Jakarta.

Suparmoko, Irawan, (1996), Ekonomika Pembangunan, BPFE Yogyakarta

Son Hyun H. \& Nanak Kakwani, 2004, Economic Growth and Poverty Reduction : Initial Conditions Matter, International Poverty Centre UNDP, Working Paper Number 2, August 2004.

Santosa, B.Purbaya \& Ashari, 2005, Analisis Statistik dengan MS. Excel dan SPSS, Penerbit ANDI Yogyakarta.

Sukirno, Sadono, 2006, Makro Ekonomi Teori Pengantar, Edisi Ketiga, Penerbit PT.RajaGrafindo Persada, Jakarta.

Sudewi, Ni Nyoman Ayu.,\& I.G.A.P.Wirathi, 2013, Pengaruh Desentralisasi Fiskal dan Pertumbuhan Ekonomi Terhadap Kemiskinan Propinsi Bali, E-Jurnal Ekonomi Pembangunan Universitas Udayana Bali Vol.2, No.3, Maret 2013 Halaman 135141.ISSN: 2303-0178

Sumbayak Daniel Judah., dkk, (2015), Pengaruh Pertumbuhan Ekonomi Terhadap Tingkat Kemiskinan di Provinsi Sumatera Selatan, Vibiz Regional Research, Magister Perencanaan dan Kebijakan Publik, Fakultas Ekonomi Universitas Indonesia Jakarta, February 2015.

Todaro, Michael P,\& Stephen C.Smith, 2006, Pembangunan Ekonomi, Edisi Ke-9 Jilid, Penerbit Erlangga Jakarta

Wirawan, Nata., 2002, Statistik 2 ( Statistik Inferensia) Untuk Ekonomi dan Bisnis, Edisi Kedua, Penerbit Keraras Emas, Denpasar Bali.

Wijayanti, Diana, dan Heri Wahono, (2005) Analisis Konsentrasi Kemiskinan Periode 19992003- Jurnal Ekonomi Pembangunan Vol.10 No.3 Desember 2005. 
Widodo, Tri, 2006, Perencanaan Pembangunan : Aplikasi Komputer (Era Otonomi Daerah), Penerbit UPP STIM YKPN Yogyakarta.

Widodo,Adi, 2011, Analisis Pengaruh Pengeluaran Pemerintah Di Sektor Pendidikan Dan Kesehatan Terhadap Pengentasan Kemiskinan Melalui Peningkatan Pembangunan Manusia Di Provinsi Jawa Tengah- Jurnal Dinamika Ekonomi Pembangunan, Juli 2011, Vol.1 No.1Undip Semarang.

http://www.sjdih.depkeu.go.id/fulltext/2011/101 PMK.02 2011PerLamp\%20III.htm www.e-akuntansi.com

pengelolaan keuangan daerah.blogspot.co.id 